THE ISOTOPIC COMPOSITION OF CARBONATE IN KIMBERLITE, MICA PERIDOTITE AND BASALT ALONG THE 38th PARALLEL LINEAMENT IN KENTUCKY AND VIRGINIA

Graham Hunt, Department of Geology, University of Louisville, Louisville, Kentucky, 40208

The close and intimate association between carbonatites, carbonatitic material, kimberlites, and alkaline rocks poses a number of problems and this study of isotope compositions is an attempt to better understand the genetic relationship and depth of origin of these carbonate-bearing rocks.

A differentiation of the carbonatitic material from the parent magma has been proposed for various mantle originated processes (Hyndman, 1972; Mitchel1, 1970). Today there is much debate over the possible types of original compositions of the parent magma. O'Hara (1965) favors a process whereby fractional crystallization enriches the magma in volatiles, etc., to form kimberlite or carbonatite. In other cases, the carbonatite is thought to separate as immiscible liquid globules (Deines, 1970). Some workers (McGetchin and Silver, 1972) have suggested that the low velocity zone may have provided the constituents necessary for the carbonatitic material.

Analyses of fluid inclusions in peridotite minerals suggest that $\mathrm{CO}_{2}$ is a dominant volatile species in the upper mantle (Roedder, 1965). Green (1972) preferred $\mathrm{CO}_{2}$ dissolved in crystalline silicates, exsolving to form the fluid inclusions. Recently, Eggler (1976) concluded that at depths of less than $90 \mathrm{~km}$ in suboceanic mantle, $\mathrm{CO}_{2}$ may be present in carbonate minerals (or in vapor, depending upon the geotherm), but cannot be in solution in silicate peridotite minerals. However, beneath the continents he suggests that $\mathrm{CO}_{2}$ will be present in carbonate minerals, and the mantle will not melt at least to depths of $120 \mathrm{~km}$. Irving and Wyllie (1973) also pointed out that the carbonate minerals in the mantle may be the site of $\mathrm{CO}_{2}$.

Because of the abundant carbonate-bearing mafic alkalic igneous rocks including kimberlite and ultramafic intrusives that are distributed along the 38th Parallel Lineament and show a close agreement between the time of movement of the lineament and the time of intrusion, an attempt is undertaken to better understand these relationships (Hunt, 1976).

The spatial distribution of the igneous rocks within a local area is related to segments forming the Lineament but the occurrence of kimberlites of eastern Kentucky, the mica peridotites of western Kentucky, and the basalt of Virginia may be related in terms of an overall structural pattern involving possible ancient plate margins and chemical plumes.

\title{
Interpretation of Results
}

Figure 1 and Table 1 show the carbon and oxygen isotopic compositions of carbonate samples studied of kimberlite, carbonatite, mica peridotite, basalt, alnoite, marine limestone, and altered ore-rich limestone. The isotopic compositions are expressed in the standard delta notation as per mil deviations from the PDB standard for carbon and from the SMOW standard for oxygen. 
The variation in isotope values may be due to a number of factors if some assumptions are taken. The dikes of western Kentucky and the kimberlites of eastern Kentucky may form a related petrographic province, in that they appear to have similar ages, are related to the 38th Parallel Lineament, same structural feature, and have similar silica contents. The chemical analyses taken from the literature (Koenig, 1956) for these rocks suggests a standard differentiation trend from a common parental source. The variation in chemical composition shows an increase in $\mathrm{K}$ and $\mathrm{Na}$, and iron as a result of differentiation with time. There would be a preference of $\mathrm{Mg}$ over $\mathrm{Fe}$ in earlier formed minerals, and therefore, Fe becomes concentrated in the late fraction of the melt. If these rocks had a common source, the higher $\mathrm{Mg}$ content and lower Fe would represent an earlier and deeper source for the kimberlites of eastern Kentucky than the mica peridotites that are enriched in $\mathrm{Fe}$ and poorer in $\mathrm{Mg}$ than the kimberlites.

Therefore, the crystallization after differentiation of the primary calcite from the parent source the residual magma would be enriched in 018 and expressed in the late forming calcite of the mica peridotite. The main factors such as variations in depth of intrusion, temperature, $\mathrm{P}_{\mathrm{H}_{2}} \mathrm{C}_{2} \mathrm{P}_{\mathrm{CO}} 2$ will have an effect on the isotope ratios at the time of formation of the calcite.

The possibility of calcite as being a weathered product, the result of assimilation of rock fragments, a result of younger thermal solutions cannot be ignored. Even though samples came from drill cores beneath the surface, 270 to 329 feet depths, the carbonate of the Hutson dike represents ore carbonate replacement shown by the unusual isotope ratios. The oxygen isotope ratios in carbonates can be altered by post emplacement exchange with meteoric waters. It is possible to argue for the preservation of the ratios on the basis of observed textures, but in some cases there is evidence of crosscutting alterations in the form of calcite recrystallization and veining in the Hutson dike.

If the isotope ratios now observed in the rocks do represent the original ones, then it is possible to make some observations about conditions during and after the time the rocks were formed. The igneous rocks of eastern Kentucky are all realtively fresh, showing little or no obvious weathering. There are no subsequent thermal events in the area that would cause metamorphic decarbonation of the carbonates that would lower the isotope ratios in the residual carbonate as observed by Deines (1969) in the Montreal area of Quebec. If the isotope ratios represent changes during magmatic differentiation over a proposed chemical plume, then there may be a common source area of isotopically homogeneous material. The limited data suggests that differences do exist between comagmatic rock types; kimberlite, mica peridotite, and a basaltic dike. These rocks may represent different fractions of a parent magma which differentiates within the mantle, giving rise to a chemical plume (model of Anderson, 1975) followed by plate movement.

Carbon isotope ratios may be used as tracers of depth of origin for a particular tectonic grouping and in conjunction with the oxygen ratios they may be used to determine the effects of post-magmatic exchange. The calcite of the western Kentucky dikes and the eastern Kentucky kimberlites occurs as medium to fine-grained aggregates which is interpreted to be a late magmatic crystallizing mineral, but in some cases the calcite phenocrysts of the western Kentucky dikes is interpreted to be the original mineral composition formed at depths of about 90 to $120 \mathrm{~km}$. 
TABLE 1: Isotopic compositions of carbonate samples studied of kimberl1te, 11meatone, carbonatite, mica peridotite, and basalt

\begin{tabular}{|c|c|c|c|}
\hline Sample localities & Description. (\%) & 3 PDB & $0^{18}$ SMOW \\
\hline EL-100 K1mberlite from locality 1 Elliott County & $\begin{array}{l}14 \text { calcite, } 23 \text { opaq., } 7 \text { rock frag., } \\
41 \text { ollvine, } 12 \text { serp. }\end{array}$ & -4.6 & +11.6 \\
\hline EL-200 Kimberlite from locality 2 Elliott County & $\begin{array}{l}12 \text { calcite, } 22 \text { opaq., } 2 \text { rock frag., } \\
45 \text { ollvine, } 17 \text { serp. }\end{array}$ & -3.7 & +18.2 \\
\hline EL-304 Kimberlite from locality 3 Elllott County & $\begin{array}{l}9 \text { calcite, } 12 \text { opaq., } 14 \text { rock frag., } \\
37 \text { ollvine, } 21 \text { serp. }\end{array}$ & -6.0 & +14.2 \\
\hline EL-302 Rock frag. in kimberlite & $\begin{array}{l}27 \text { calcite, } 63 \text { fine grain. (serp?) } \\
\text { unidentified }\end{array}$ & -6.1 & +15.9 \\
\hline $\begin{array}{l}\text { NW-Y-71 Newman I.s. Stop } 10 \text { KGS conf. } \\
\text { Grayson, Ky }\end{array}$ & 62 calcite, 35 clay, 3 qtz. & -1.6 & +21.5 \\
\hline EL-207 Limestone from locality 2 Elliott County & 38 calcite, 60 clay & -0.3 & +23.2 \\
\hline S-6c Carbonatite Oka Complex, Que. & $\begin{array}{l}90 \text { calcite, } 5 \text { apatite, pyroxene, } \\
5 \text { blotite }\end{array}$ & -5.7 & +4.1 \\
\hline Ark -K2 Carbonatite, Kimsey Quarry, Ark. & all calcite & -5.6 & +5.8 \\
\hline HT-1 Hutson Dike Livingston County, Kentucky & $\begin{array}{l}57 \text { calcite, } 3 \text { serp., } 34 \text { opaq., } \\
\text { perovskite, } 6 \text { mica, apatite, qtz. }\end{array}$ & +1.4 & +27.8 \\
\hline HB-2 Hobby Dike Caldwell County, Kentucky & $\begin{array}{l}21 \text { calcite, } 41 \text { serp., } 23 \text { mica, } 7 \\
\text { opaq., apatite, } 8 \text { sphene, clinozoisite, } \\
\text { perovsklte }\end{array}$ & -3.88 & +17.95 \\
\hline F-5 Flanary Dike Crittenden County, Kentucky & $\begin{array}{l}42 \text { calcite, } 24 \text { serp., } 19 \text { mica, } \\
14 \text { opaq., apatite perovskite }\end{array}$ & -4.89 & +19.68 \\
\hline SC-2 She11 Core Dike, Crittenden County, Kentucky & $\begin{array}{l}22 \text { calcite, } 38 \text { serp., } 27 \text { mica, } 11 \\
\text { opaq., apatite, } 2 \text { clinozolsite, } \\
\text { perovskite }\end{array}$ & -2.90 & +19.02 \\
\hline Va-2 Basaltic Dike Highland County, Virginia & $\begin{array}{l}9 \text { calcite, opaq., } 90 \text { bio., plag., } \\
\text { pyroxene }\end{array}$ & -3.3 & +21.88 \\
\hline
\end{tabular}

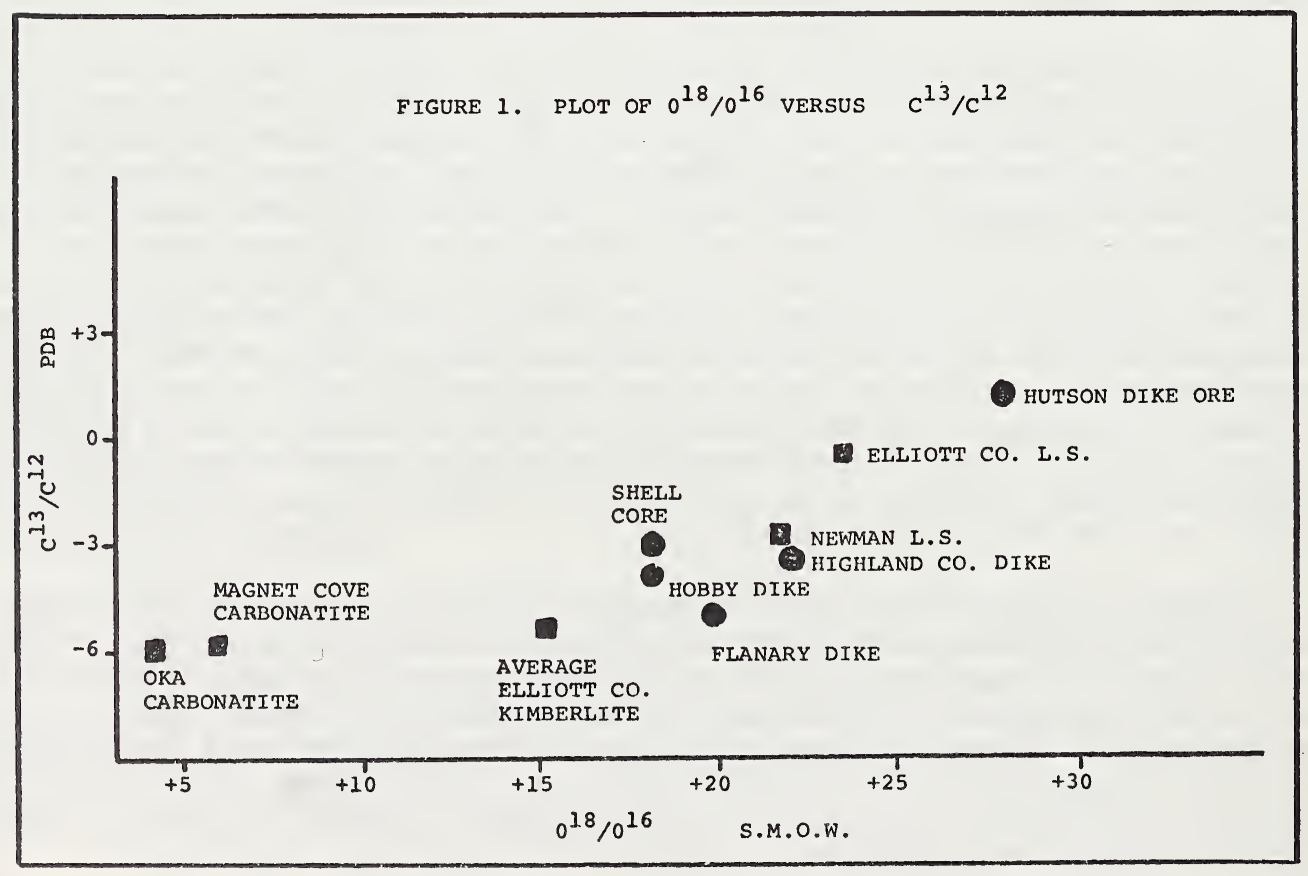

